\title{
Quantitative estimation of some essential minerals in the fruit of Neolamarckia cadamba
}

\author{
Imana Pal, Avinanda Majumdar' Kazi Layla Khaled, Santa Datta (De) \\ Department of Home Science, University of Calcutta, India
}

\begin{abstract}
Neolamarckia cadamba (Roxb.)Bosser commonly called kadam enjoys a hallowed position in Ayurveda. This study is to make a quantitative estimation of some important minerals like $\mathrm{Fe}, \mathrm{Ca}, \mathrm{Mg}, \mathrm{Cr}, \mathrm{Pb}$, $\mathrm{Cd}, \mathrm{Zn}, \mathrm{Se}, \mathrm{Cu}$, and $\mathrm{P}$ of the fruit (ripe) of Kadam. The fruit has been reported to be edible. The data obtained from this study show that $100 \mathrm{~g}$ of the edible portion of the fruit contains $40.02 \mathrm{mg} \mathrm{Fe}, 343.7 \mathrm{mg} \mathrm{Ca}, 191.7 \mathrm{mg} \mathrm{Mg}$, 2.434mg $\mathrm{Zn}, 2.362 \mathrm{mg} \mathrm{Cr}$, and $1.344 \mathrm{mg} \mathrm{Cu}$.
\end{abstract}

Keywords: Ayurveda, Kadam, Iron, Calcium, Magnesium, Zinc, Neolamarckia cadamba

\section{Introduction}

Neolamarckia cadamba also known as kadam, is a tropical tree species that is native to South Asia and Southeast Asia. It belongs to the family of Rubiaceae. The synonyms used for this plant are Anthocephalus cadamba, Anthocephalus indicus, Sarcocephalus cadamba (Roxb. $)^{1}$ etc. Kadam is a large tree with a broad umbrella-shaped crown and straight cylindrical bole. The branches are characteristically arranged in tiers. The tree usually reaches a height of $45 \mathrm{~m}$ with a stem diameter of $100-160 \mathrm{~cm}^{2}$.

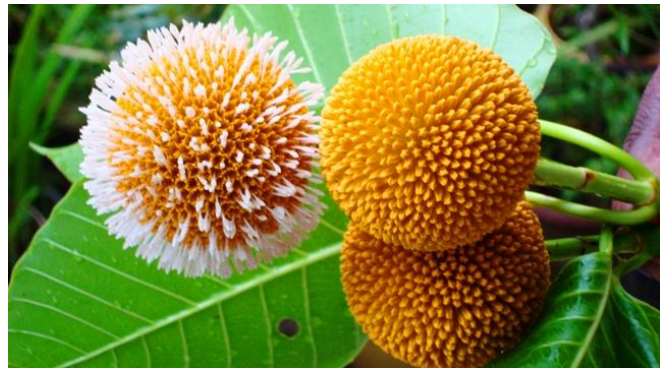

Kadam flowers

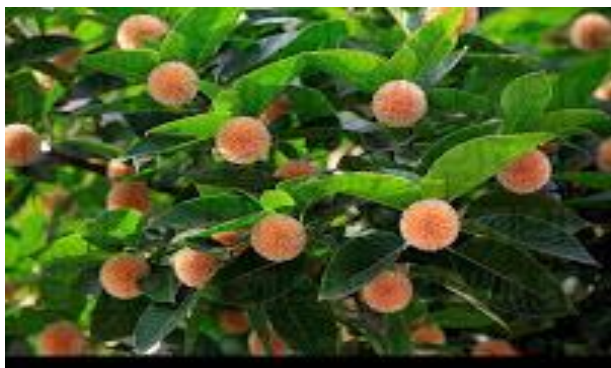

Full bloomed kadam flowers in a tree

The fruitlets are numerous, somewhat fleshy, with their upper parts containing four hollow or solid structures. The fruit occurs in small, fleshy capsules packed closely together to form a fleshy yellow-orange infructescence containing approximately 8000 seeds. The ripe fruits have been reported to be edible in raw state $^{3}$.The seeds somewhat are trigonal or irregular shaped, not winged ${ }^{2}$.

Phytochemical investigation of different parts of Neolamarckia cadamba showed the presence of chemical constituents such as indole alkaloids, terpenoids, saponins, sapogenins, terpenes, steroids, fats, reducing sugar, glycosides, and flavonoids ${ }^{4}$. The isolated principle are glycosidic indole alkaloids; cadambine, 3alpha-dihydrocadambine, isodihydrocadambine, and two related non-glycosidic alkaloids. The bark also consists of tannins and an astringent principle; which is due to presence of an acid similar to cincho-tannic acid ${ }^{4}$.

Studies showed that the almost all parts of the plant kadam are used in the treatment of various diseases. Decoction of leaves is used in aphthae or stomatitis, ulcers, wounds ${ }^{5}$. The root and leaf extract of kadam showed hypoglycaemic effect ${ }^{6,7}$. The bark extracts showed good genoprotective potential comparable to gallic acid. The flower extract of kadam showed a marked increase in serum levels of aspartate transaminase (AST), alkaline phosphatase (ALP), glutamate pyruvate transaminase activity (GPT) and total bilirubin, and reduction of superoxide dismutase, catalase levels in liver $^{8}$. 


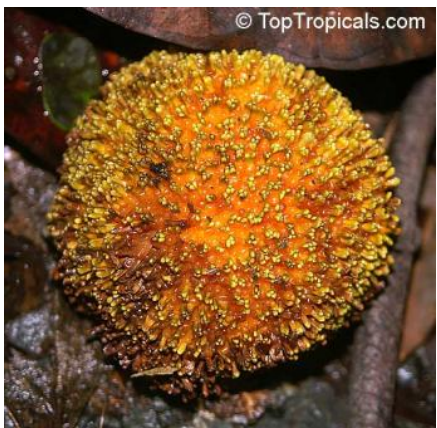

Ripe kadam fruit

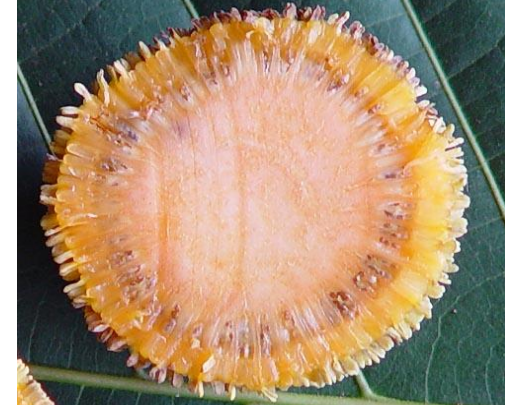

Cross section of a ripe kadam fruit

The fruits showed significant antibacterial activity against different microorganisms and especially good result against E. coli ${ }^{9}$. Green fruit also exerts wound healing and antioxidant property because of terpenoids. Ripened fruit is a better wound healer and a traditional remedy for urinary tract problems because of the presence of tannins along with terpenoids ${ }^{10}$.

It has been reported that the ripe fruits are edible in raw state ${ }^{3}$. But there is no evidence of any research work on the nutritive values of the fruit of Neolamarckia cadamba.

\subsection{Collection of the sample}

\section{Materials And Methods}

Kadam fruits were collected from the adjacent garden of Department of Home science campus, University of Calcutta.

\subsection{Preparation of sample}

The ripe whole fruit was selected as the test portion for the quantitative estimation of the minerals.

\subsection{Preparation of working solution}

The working solution was prepared for measuring the following minerals $\mathrm{Fe}, \mathrm{Ca}, \mathrm{Mg}, \mathrm{Zn}, \mathrm{Cr}, \mathrm{Cu}, \mathrm{Pb}$,

Se, P, Cd using AOAC method. ${ }^{11}$ The instrument used for mineral estimation was ICP (OES), model

ICAP6800, serial number ICP 20073108 ,calibrated with NIST certified multi-standards.

\section{Results}

Table 1: Mineral content of fruit of Neolamarckia cadamba

\begin{tabular}{|c|c|}
\hline Minerals & $\mathbf{m g} / \mathbf{1 0 0}$ gm whole fruit \\
\hline 1.Iron & 40.02 \\
\hline 2.Calcium & 343.7 \\
\hline 3.Magnesium & 191.7 \\
\hline 4.Zinc & 2.434 \\
\hline 5.Chromium & 2.362 \\
\hline 6.Copper as Cu & 1.344 \\
\hline 7.Lead as Pb & 0.089 \\
\hline 8.Selenium & 0.052 \\
\hline 9.Phosphorous & 0.003 \\
\hline 10.Cadmium & ND (DL-0.1 mg/100gm) \\
\hline
\end{tabular}

ND: Not detected

DL: Detection limit

This table shows a considerable amount of Iron, Calcium and Magnesium content in the fruit of Neolamarckia cadamba.

Table 2: Comparison of mineral content of apple, rose apple, pear, water chestnut, dates (as per ICMR Values) ${ }^{12}$ with kadam (obtained in this study)

\begin{tabular}{|l|l|l|l|l|l|l|}
\hline \multicolumn{1}{|c|}{ Fruits } & \multicolumn{1}{|c|}{$\begin{array}{c}\text { Calcium } \\
\mathbf{m g} / \mathbf{1 0 0} \mathbf{g m}\end{array}$} & \multicolumn{1}{|c|}{$\begin{array}{c}\text { Iron } \\
\mathbf{m g} / \mathbf{1 0 0} \mathbf{g m}\end{array}$} & $\begin{array}{c}\text { Magnesium } \\
\mathbf{m g} / \mathbf{1 0 0} \mathbf{g m}\end{array}$ & $\begin{array}{c}\text { Zinc } \\
\mathbf{m g} / \mathbf{1 0 0} \mathbf{g m}\end{array}$ & $\begin{array}{c}\text { Copper } \\
\mathbf{m g} / \mathbf{1 0 0} \mathbf{g m}\end{array}$ & $\begin{array}{c}\text { Phosphorous } \\
\mathbf{m g} / \mathbf{1 0 0} \mathbf{g m}\end{array}$ \\
\hline Apple & 10.00 & 0.66 & 7.00 & 0.06 & 0.10 \\
\hline Rose apple & 10.00 & 0.50 & 4.00 & - & 0.10 \\
\hline Pear & 8.00 & 0.50 & 7.00 & - & 0.40 & 14.00 \\
\hline Water chestnut & 70.00 & 2.40 & 72.00 & 1.56 & 1.31 \\
\hline Dates (fresh) & 22.00 & 0.96 & 12.00 & 0.03 & 0.05 \\
\hline Kadam & $\mathbf{3 4 3 . 7 0}$ & $\mathbf{4 0 . 0 2}$ & $\mathbf{1 9 1 . 7 0}$ & $\mathbf{2 . 4 3}$ & 440.00 \\
\hline
\end{tabular}

Table-2 shows that kadam fruit is an excellent source of $\mathrm{Ca}, \mathrm{Fe}, \mathrm{Mg}, \mathrm{Zn}$ as compared to our popular fruits like apple, rose apple, pear, water chestnut and dates. 


\section{Discussion}

From this it may be concluded that kadam fruit is a rich source of $\mathrm{Ca}, \mathrm{Fe}, \mathrm{Mg}, \mathrm{Zn}$ and also have considerable amount of $\mathrm{Cu}, \mathrm{P}, \mathrm{Se}, \mathrm{Cd}$ are low. Furthermore the fruit contains higher amount of $\mathrm{Ca}, \mathrm{Fe}, \mathrm{Mg}, \mathrm{Zn}$ in comparison to some commonly edible fruits.

Thus kadam fruit is a good source of important minerals, and can be placed at par with some well known and expensive fruits like apple, pear etc in terms of their mineral content. However, being unfamiliar as a fruit or ignorance about its edibility, such a rich resource of minerals has remained neglected. The fruit is therefore an easily available source of nutrients and inexpensive and has been reported to be used in different food preparations by tribal people. Hence, it may be promoted among economically backward sections of people who are not able to procure the more expensive fruits.

\section{References}

[1]. Martawijaya, A., Kartasujana, I., Mandang, Y.I., Prawira, S.A. and Kadir, K. (1989) Atlas kayu Indonesia Jilid II. Pusat Penelitiandan PengembanganHasi lHutan, Bogor, Indonesia.

[2]. Soerianegara, I. and Lemmens, R.H.M.J. (1993) Plant resources of South-east Asia 5 (1): Timber trees: Major commercial timbers. Pudoc Scientific Publishers, Wageningen, Netherlands.

[3]. Bandyopadhyay S., Mukherjee S, (2009), Wild Edible Plants of Koch Bihar District, West Bengal. Kr., Natural Product Radiance, Vol. 8(1), pp. 64-72.

[4]. Gautam R, Irchhaiya R, Swarnakar R, (2012), Anthocephalus cadamba (ROXB): An overview , India, International Journal of Pharmaceuticals Research and Development (IJPRD), IJPRD; Vol. 4(04): pp. 169-173.

[5]. Dubey A, Nayak s, Goupale D.C (2011), A Review on Phytochemical, Pharmacological and Toxicological Studies, Scholars Research Library Der Pharmacia Lettre, 3(1): pp 45-54.

[6]. Acharyya S, Dash G.K, Mondal S, Dash S.K, (2010) Studies on Glucose Lowering Efficacy of the Anthocephalus Cadamba (ROXB.) Miq. Roots, International Journal of Pharma and Biosciences, 1(2) article 79 pp. 9.

[7]. Ahmed F, Rahman S. Ahmed N, Hossain M, Biswas, A. Sarkar S. Banna, Afsana Khatun, Chowdhury M H, Rahmatullah M,(2011) Evaluation of Neolamarckia Cadamba (ROXB.) Bosser Leaf Extract on Glucose Tolerance in Glucose-Induced Hyperglycemic Mice, African Journal of Traditional, Complementary and Alternative Medicines, Vol. 8, No. 1, pp. 79-81

[8]. Malothu R, Nalini Mathala, Adarsh G, Muralidhara Rao D,(2012) Hepatoprotective Activity and Antioxidant Activity of Anthocephalus Indicus in Ethanol Induced Hepatotoxicity in Albino Wister Rats, International Journal of Phytopharmacology. 3(3), pp 245-248

[9]. Mishra R.P, Sr. Research Scientist (2011)_,Antibacterial Properties of Anthocephalus Cadamba Fruits. Webmed Central AYURVEDIC MEDICINE2(8):WMC002073

[10]. Mishra R.P.Sr. Research Scientist (2011), A Comparative Study and Extract Optimization for Antimicrobial Properties of Different Parts of AnthocephalusCadamba.WMC00211, SSN 2046-1690.

[11]. Dr. Horwitz W., editor, Dr. Latimer G., junior editor, AOAC $18^{\text {th }}$ Edition, 2005, current through Revision 1, 2006.

[12]. Gopalan C, Ramasastri B.V, Balasubramaniam S.C, (2010),Nutritive Value of Indian Foods, National Institute of Nutrition Hyderabad, ICMR. 